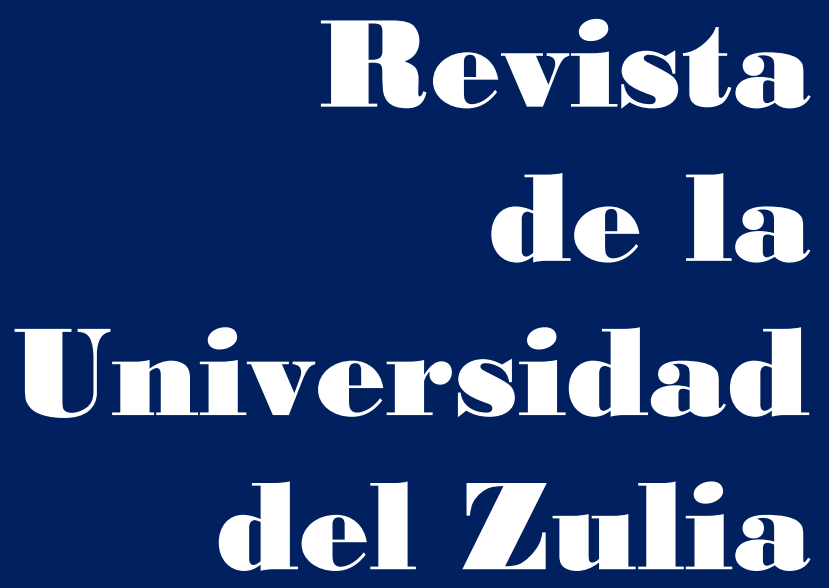

Fundada en 1947

por el Dr. Jesús Enrique Lossada

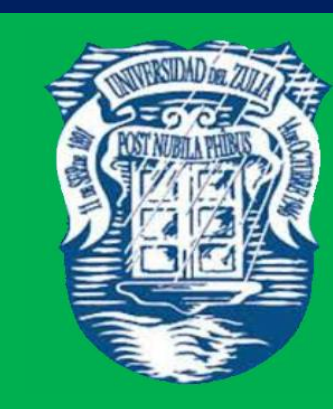

Ciencias del

Agrad,

Ingemiería

y Tecinología

\section{Aกัต 13 No $\mathbf{3 6}$} Enero - Abril 2022

Tercera Épaca

Maracailbo-Venezuela 


\title{
Formation of a rational technology for service cargo points at railway connecting lines of industrial enterprises
}

\author{
Hanna Sergiivna Baulina * \\ Hanna Yevhenivna Bohomazova ** \\ Svitlana Mykolaivna Prodashchuk ***
}

\begin{abstract}
The aim of the article is to define of rational technology for service cargo points at railway connecting lines of industrial enterprises taking into account possible penalties. To solve this problem, the authors used methods of analysis of statistical data of dynamically changing parameters, methods of simulation modeling, mathematical statistics, probability theory and methods of combinatorial analysis. In the work is formalized the rational technology for service at railway connecting lines of industrial enterprises in the form of a mathematical model. The objective function of the model uses the criterion of total operating expenses and takes into account the probabilistic nature of the waiting time for dispatching of wagons to the cargo point. The mathematical model is designed to determine the rational number of wagons in the dispatching to the cargo point at railway connecting lines of industrial enterprises. The proposed technology takes into account penalties for violation of the delivery time.
\end{abstract}

KEY WORDS: railway transport; appropriate technology; railway connecting lines of industrial enterprises; operational expenses.

*PhD in Technical Sciences, Associate Professor at the Department of Freight and Commercial Management of Ukrainian State University of Railway Transport. ORCID ID: https://orcid.org/0000-0001-8464-1507. E-mail: baulina777@gmail.com

**PhD in Technical Sciences, Associate Professor at the Department of Freight and Commercial Management of Ukrainian State University of Railway Transport. ORCID ID: http://orcid.org/00000002-8042-0624

***PhD in Technical Sciences, Associate Professor at the Department of Freight and Commercial Management of Ukrainian State University of Railway Transport. ORCID ID: http://orcid.org/00000002-7673-3863 


\section{La formación de la tecnología racional del servicio de los puntos de carga para las vías férreas de las empresas industriales}

RESUMEN

El propósito del artículo es determinar la tecnología racional de servicio de los puntos de carga de las vías férreas de las empresas industriales, teniendo en cuenta las posibles sanciones. Para resolver este problema, los autores utilizaron métodos de análisis de datos estadísticos de parámetros que cambian dinámicamente, métodos de simulación, estadística matemática, teoría de la probabilidad y métodos de análisis combinatorio. En el trabajo se formaliza la tecnología racional del servicio de los puntos de carga de las vías férreas de las empresas industriales en forma de modelo matemático. La función objetivo del modelo utiliza el criterio de los costos operativos totales y tiene en cuenta la naturaleza probabilística del tiempo de espera de los vagones para alimentar a los puntos de carga. El modelo matemático está diseñado para determinar el número racional de automóviles en el suministro al punto de carga de las vías férreas de las empresas industriales. La tecnología propuesta tiene en cuenta las sanciones por incumplimiento del plazo de entrega.

PALABRAS CLAVE: transporte ferroviario; tecnología adecuada; vías férreas de empresas industriales; costos operativos.

\section{Introduction}

Railway connecting lines of industrial enterprises are an important element in the logistics network of material flows. They provide direct interaction in the transfer of goods between the main railway transport and cargo owners. Ukraine's transport system includes more than 7,000 railway connecting lines of industrial enterprises with a total length of more than 27,000 km (Shumik et al., 2016). The maintenance of railway connecting lines of industrial enterprises consists in the dispatching of wagons for freight operations and the picking of loaded or empty wagons from cargo points.

Analysis of the work at the railways of Ukraine shows that more than 90\% of all freight work is performed on the enterprise's railway connecting lines (Miletska, 2010). Circumstances that arise between the adjacent station and the railway connecting lines of industrial enterprises when processing wagons can lead to breaches of contractual obligations and significant penalties. Today's level of transport service of production units does not fully meet the requirements of all participants in the transport and production chain of cargo transportation (Baulina et al., 2021). Even in the presence of a reserve of railway 
REVISTA DE LA UNIVERSIDAD DEL ZULIA. 3e época. Año 13 N$^{\circ}$ 36, 2022

Hanna Sergiivna Baulina et al. // Forming a rational technology for service cargo points... 357-372 DOI: http://dx.doi.org/10.46925//rdluz.36.23

rolling stock, industrial enterprises and railways incur production losses due to late transport services and penalties for non-compliance with the terms of the contract. Therefore, the task of improving the technology of interaction between stations and railway connecting lines of industrial enterprises, which combine organizational issues with the problems of rational technical equipment and the number of technical means, is urgent. This approach reduces the length of stay of wagons on the railway connecting lines of industrial enterprises and stations. And, as a consequence, the reduction of downtime and turnover of the freight wagon while reducing operating expenses.

In this regard, the aim of this study is devoted to define of rational technology for service cargo points at railway connecting lines of industrial enterprises taking into account possible penalties.

\section{Literature review}

One of the important conditions for the successful development of freight traffic on the railways is the constant improvement of technology for managing traffic flows while reducing the operating expenses of the railway and meeting the needs of cargo owners. This will speed up the delivery of goods and eliminate obstacles to infrastructure capacity (Butko et al., 2019).

Today, the existing system an organization for service at railway connecting lines of enterprises demonstrates its inefficiency. The existing procedure for the distribution of empty wagons at enterprises leads to an imbalance in the existing fleet of wagons with the need for transportation of goods or export of finished products and their irrational use (Baulina and Zakharova, 2017). In modern conditions, there is improper use of railway wagons on the enterprise's railway connecting lines, especially at coal and metallurgical companies. At these enterprises sometimes the residence time of wagons exceeds the norm by several times. As a rule, the most time is spent waiting to be picked up from the adjacent station. Sometimes wagons are used as warehouses on wheels or for internal movement goods in the absence of its own rolling stock (Zapara and Garbuzov, 2015). The technological aspect of the problem interaction between stations and enterprise's railway connecting lines requires the need to perform operations of processing cars on a single technology. This 
REVISTA DE LA UNIVERSIDAD DEL ZULIA. 3ํépoca. Año $13 \mathrm{~N}^{\circ}$ 36, 2022

Hanna Sergiivna Baulina et al. // Forming a rational technology for service cargo points... 357-372 DOI: http://dx.doi.org/10.46925//rdluz.36.23

requires consistency of technological processes performed at railway stations, enterprise's railway lines and ports (Baulina and Bohomazova, 2020).

Baulina $H$. proposed in her study a model that will determine the number of dispatching of wagons on the freight front. This will reduce unproductive wagons idle time at the station and increase the processing capacity of the freight front. The developed model can be considered rather universal in the structure and to use it at receipt of wagons on a goods shed of station for performance of freight operations (Baulina, 2013). To substantiate the choice of effective modes of interaction between railway stations and non-public railway lines, the functional dependences have been improved to determine the optimal values of the intervals between the dispatching of wagons to the loading and unloading fronts. Formulas for determining the duration of shunting operations with wagons that depend on certain parameters are also obtained (Yelovoy and Potylkin, 2016).

To solve the problem of optimal distribution of empty wagons in railway transport hubs, it is proposed to use a model that takes into account the requirements of wagon owners for their use. The model also takes into account the operational level to loading of railway stations in the node and the possibility to including groups of empty wagons in the composition of transfer, removal trains and trains that run on the contact schedule (Rakhmangulov et al., 2014). Fukasawa R. proposed a method for determining the optimal flow of loaded and empty wagons in order to maximize profits, income from the tonnage transported, taking into account the train schedule together with traction capabilities (Fukasawa et al., 2002). A space-time model of network flows can be used to plan rail transportation from suppliers to customers (Lawley et al., 2008). The model uses a variety information, including consumer demand, railway network characteristics, loading and unloading times, and the capacity of stationary devices to handle incoming wagon traffic. The proposed model is based on the maximum level of loading of goods shed while minimizing the waiting time for loading and unloading of the main freight.

The model, optimizing the purpose of heterogeneous empty freight wagons, presented by Narisetty A., allowed to optimize transport expenses. And also strictly adhere to the delivery deadline, which allows to achieve a significant reduction in transportation expenses (Narisetty et al., 2008). Sayarshad H. and Marler T. presented the development of an analytical solution for the size of the fleet of wagons. Their analysis tool includes 
REVISTA DE LA UNIVERSIDAD DEL ZULIA. 3e época. Año 13 N$^{\circ}$ 36, 2022

Hanna Sergiivna Baulina et al. // Forming a rational technology for service cargo points... 357-372 DOI: http://dx.doi.org/10.46925//rdluz.36.23

opportunities to optimize the use of rolling stock, assess the profitability of efficient promotion of goods and check the quality for services provided to customers (Sayarshad and Marler, 2010).

Improving the technology of interaction between the station and the adjacent enterprise's railway connecting lines is possible with a differentiated approach to the sender and recipient. When establishing the order of customer service, it is proposed to take into account the number of wagons of different types arriving or departing, the volume of loading and unloading on the enterprise's railway connecting lines, the uneven arrival of local wagons at the station and other factors (Shumik et al., 2016).

Freight wagons spend a significant part of their time under freight operating stations and loading points of access roads. These are the most time-consuming, complex and expensive jobs, the efficiency of which is significantly affected by the technology of work. To reduce the costs incurred during cargo operations, it is necessary to determine the most rational technologies of work with the optimal distribution of loading and unloading resources, the use of which will determine the most rational technology of work by reducing operating costs. But the paper does not consider the number of feedings on cargo fronts (Prodashchuk et al., 2017).

The analysis of scientific works showed that a significant part of them is aimed at solving the issue of regulating the movement of wagons at stations, taking into account the minimization of downtime and increase capacity. For cargo stations, the methods of operational dispatching influence on the congestion of station facilities were proposed, and on the railway connecting lines of industrial enterprises the technologies of interaction with the adjacent service stations were proposed. The interaction of cargo stations and railway connecting lines was considered from the standpoint of maximum loading and unloading capacity at cargo points. In modern conditions it is necessary to take into account the ability of infrastructure to handle the growing volume of wagon traffic. As well as take into account the random nature of the arrival of wagons at stations and cargo points, as well as possible fines associated with breach of contractual terms of transportation of goods for service railway connecting lines of industrial enterprises.

\section{Methodology}


REVISTA DE LA UNIVERSIDAD DEL ZULIA. 3e época. Año 13 N$^{\circ}$ 36, 2022

Hanna Sergiivna Baulina et al. // Forming a rational technology for service cargo points... 357-372 DOI: http://dx.doi.org/10.46925//rdluz.36.23

This work uses the analysis methods of statistical data of the local wagon idle time at the railway station from 2016 to 2020. There were used the data of time-based field observations of the duration of technical and commercial inspections of wagons, time for dispatching-picking of wagons at cargo points, waiting time for dispatching-picking of wagons and doing cargo operations, other parameters to determine the duration of the main technological operations and their waitings.

Simulation modeling methods were used for formalizing the rational technology for service cargo points at railway connecting lines of industrial enterprises. Methods of processing the results of monitoring with the subsequent application of probability theory and mathematical statistics were also used to define the waiting time for the dispatching of wagons to the cargo point. Combinatorial analysis methods were used to determine the rational technology for service cargo points at railway connecting lines of industrial enterprises, taking into account possible penalties.

Application of the specified methods allows to organize work for service of cargo points on the most effective technology thanks to rational distribution of existing technical means at maintenance of the minimum operational expenses.

\section{Results and Discussions}

The authors conducted a detailed analysis of one of the most significant factors in determining the efficiency of the station, namely the comparison of planned and actual values of local wagons idle time (Figure 1). The analysis of actual and planned indicators of local wagons idle time showed that the implementation of the plan with the smallest excess is observed only in 2016. The longest local wagons idle time at the station can be observed in 2020 , it amounted to 82.76 hours - this is 38\% more than planned. The reasons for this are significant wagons idle time in anticipation of various technological operations, namely: waiting for the dispatching of wagons on the enterprise's railway connecting lines, waiting for unloading and loading operations, waiting for picking wagons from the enterprise's railway connecting lines to the station. As the analysis of the duration of wagons idle time proved, for the whole analyzed period there is a tendency to increase this indicator. 
REVISTA DE LA UNIVERSIDAD DEL ZULIA. 3e época. Año $13 \mathrm{~N}^{\circ}$ 36, 2022 Hanna Sergiivna Baulina et al. // Forming a rational technology for service cargo points... 357-372 DOI: http://dx.doi.org/10.46925//rdluz.36.23

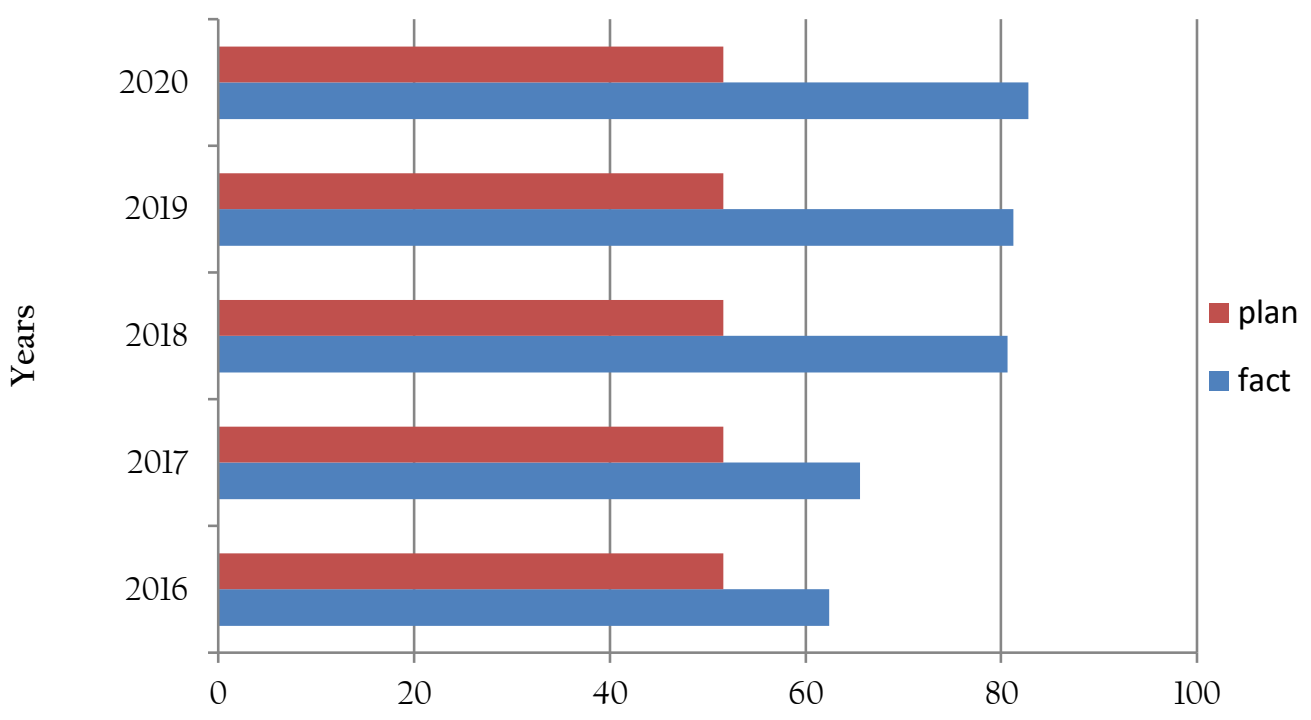

Wagons idle time, hours

Figure 1. Dynamics of local wagons idle time at the railway station Source: authors

Studies of the components of local wagons idle time have shown that we can identify three main elements, taking into account the relevant operations (Table 1). It was determined that the downtime from arrival to dispatching on the railway connecting lines of industrial enterprises for cargo operations was $51 \%$ and this is more than half of the total time spent by local wagons at the station (Figure 2).

Table 1. Components of local wagons idle time

\begin{tabular}{|l|l|}
\hline $\begin{array}{c}\text { The name of the local } \\
\text { wagons idle time } \\
\text { element }\end{array}$ & \multicolumn{1}{|c|}{ Component of the element } \\
\hline $\begin{array}{l}\text { l. Downtime from } \\
\text { arrival to dispatching on } \\
\text { the railway connecting } \\
\text { lines of industrial } \\
\text { enterprises for cargo } \\
\text { operations }\end{array}$ & $\begin{array}{l}\text { Duration of technological operations during } \\
\text { processing of trains with local wagons that arrived at } \\
\text { the station for processing, wagons idle time for } \\
\text { waiting to be disbanded, wagons idle time for waiting } \\
\text { to be dispatching to the railway connecting lines of } \\
\text { industrial enterprises }\end{array}$ \\
\hline
\end{tabular}


REVISTA DE LA UNIVERSIDAD DEL ZULIA. $3^{a}$ época. Año $13 \mathrm{~N}^{\circ}$ 36, 2022

Hanna Sergiivna Baulina et al. // Forming a rational technology for service cargo points... 357-372

DOI: http://dx.doi.org/10.46925//rdluz.36.23

\begin{tabular}{|l|l|}
\hline $\begin{array}{l}\text { 2. Downtime under } \\
\text { cargo operations }\end{array}$ & $\begin{array}{l}\text { Wagons idle time for waiting to cargo operations and } \\
\text { wagons idle time under cargo operations }\end{array}$ \\
\hline $\begin{array}{l}\text { 3. Downtime from the } \\
\text { end of cargo operations } \\
\text { to departure from the } \\
\text { station }\end{array}$ & $\begin{array}{l}\text { Duration of technological operations with local } \\
\text { wagons after the end of cargo operations before their } \\
\text { departure from the station, wagons idle time for } \\
\text { waiting to be picking from the railway connecting } \\
\text { lines of industrial enterprises to the station and } \\
\text { wagons idle time for waiting to departure }\end{array}$ \\
\hline
\end{tabular}

Source: authors
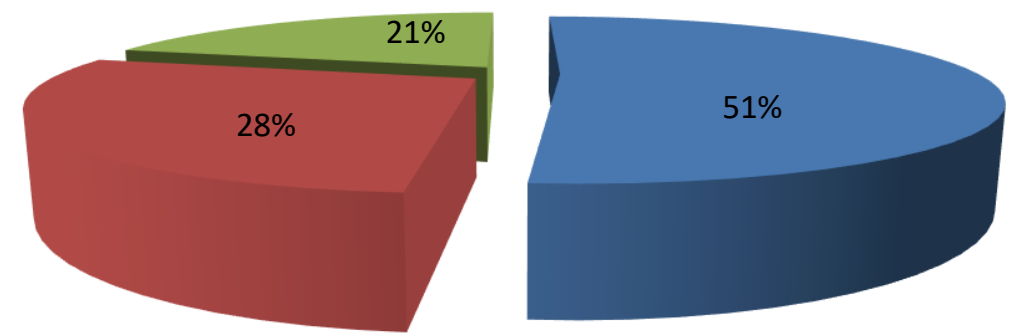

Downtime from arrival to delivery

Downtime under cargo operations

Downtime from the end of cargo operations to departure from the station

Figure 2. Diagram of the distribution of local wagons idle time by elements

Source: authors

The authors conducted a study of the distribution of local wagons idle time under the operations and in anticipation of them. It was determined that the wagon was waiting for technological operations $61 \%$ of the total time of stay the local wagon at the station, which indicates the inefficient technology of interaction between the station and the railway connecting lines of industrial enterprises (Figure 3). 


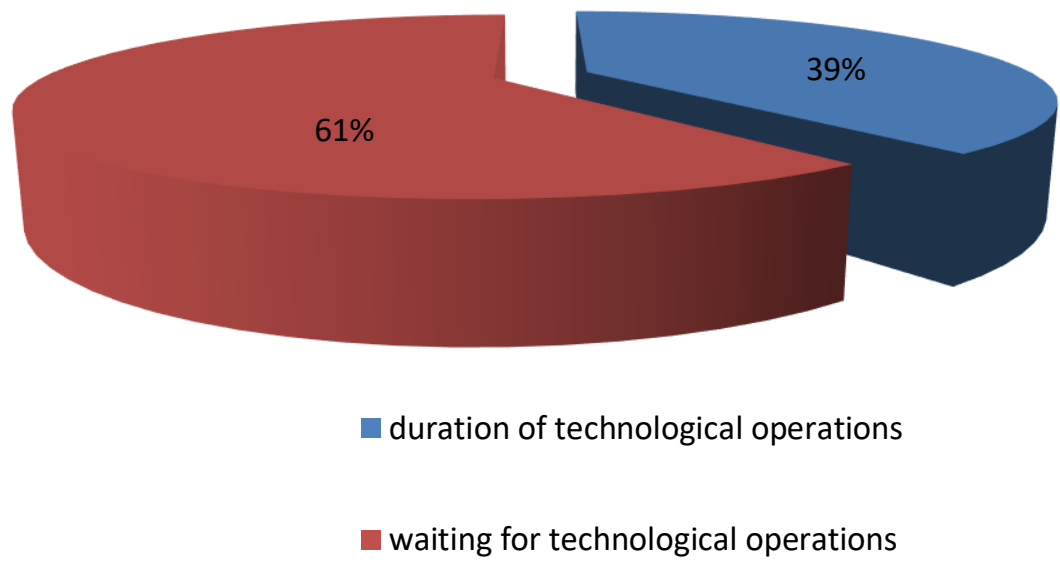

Figure 3. Diagram of the distribution of local wagons idle time during operations and in anticipation

Source: authors

Thus, to reduce inter-operational idle time of wagons, in order to improve the performance and improve the processing of wagon traffic in the interaction of the station and the railway connecting lines of industrial enterprises, it is necessary to develop a rational technology for service the cargo points at railway connecting lines of industrial enterprises.

Transport service of production units must fully meet the needs of production, which provides flexible management of the transportation process, adaptation of industrial railway transport to changes in operational volumes, determining the required size of the working fleet of wagons taking into account factors affecting the operation of industrial enterprises. In this regard, it is advisable to formalize the rational technology for service at railway connecting lines of industrial enterprises in the form of a mathematical model. This model is based on the reduction of operating expenses and the amount of possible penalties while minimizing of rolling stock idle time in anticipation of technological operations. The main penalties for the carrier are the payment of penalties for late delivery of goods. The amount of penalties for non-compliance with the contractual terms for service at railway connecting lines of industrial enterprises depends on the duration of the service delay and the number of detained wagons. 
The target function of the model a rational technology for service cargo points at railway connecting lines of industrial enterprises into account the penalty for violation of term to delivery freight will take the form:

$$
C(N)=C_{a}+C_{d}^{e x}+C_{c l}^{e x}+C_{s h}+C_{f}+C_{f o}^{e x}+C_{t c}+C_{f}^{g} \rightarrow \min
$$

when implementing a system of restrictions:

$$
\left\{\begin{array}{l}
Z_{i-c l}>0 \\
N \leq l_{c p} \\
t_{t c} \leq t_{s t} \\
t_{a c} \leq t_{d}
\end{array},\right.
$$

where $N$ is the number of wagons delivered to the cargo point; $C_{a}$ are the expenses of accumulation of a group of wagons for dispatching to the railway connecting lines of industrial enterprises; $C_{d}^{e x}$ are the expenses associated with the wagons idle time in anticipation for delivery to the cargo point; $C_{c l}^{e x}$ are the expenses associated with the wagons idle time in anticipation for removal from the cargo point after performing cargo operations with them; $C_{s h}$ are the expenses of shunting work for the dispatching and packing wagons; $C_{f}$ are the expenses associated with the time of finding wagons in the process of spotting / packing wagons; $C_{f o}^{e x}$ are the expenses associated with the anticipation of wagons the cargo operations; $C_{t c}$ are the expenses of technical and commercial inspections of wagons; $C_{f}^{g}$ is a fine for late delivery of goods, if the delay is the fault of the adjacent station; $Z_{i-c l}$ is the number of spotting / picking wagons; $l_{c p}$ is the length of the cargo point in the wagons; $t_{t c}$ is duration of technical and commercial inspections of wagons; $t_{s t}$ is standard time of technical and commercial inspections of wagons; $t_{a c}$ is actual time of delivery; $t_{d}$ is freight delivery time.

The second restriction prevents the dispatching of wagons to the cargo point in quantities exceeding the capacity of this cargo point. The third restriction stipulates that the duration of technical and commercial inspections of wagons must not exceed the standard 
REVISTA DE LA UNIVERSIDAD DEL ZULIA. $3^{a}$ época. Año $13 \mathrm{~N}^{\circ}$ 36, 2022

Hanna Sergiivna Baulina et al. // Forming a rational technology for service cargo points... 357-372

DOI: http://dx.doi.org/10.46925//rdluz.36.23

time. The fourth condition reflects the fulfillment of restrictions on the delivery freight in the established terms.

The expenses of accumulation for a group of wagons for dispatching to the railway connecting lines of industrial enterprises:

$$
C_{a}=\frac{C_{s t} \sum_{i=1}^{k} N_{i} t_{i}}{\lambda}
$$

where $C_{s t}$ are the expenses of storing the wagon under the accumulation for dispatching to the railway connecting lines of industrial enterprises; $\sum_{i=1}^{k} N_{i} t_{i}$ - wagon-hours idle time under accumulation; $\lambda$-traffic intensity of wagons dispatching to the railway connecting lines of industrial enterprises.

The expenses associated with the wagon idle time for waiting to be dispatching to the to the cargo point calculated by the formula:

$$
C_{d}^{e x}=N t_{e x . d} C_{w h}
$$

where $C_{w h}$ is the cost of one wagon-hour idle time; $t_{e x . d}$ is duration of wagons waiting for dispatching to the cargo point.

Studies have shown that the waiting time for dispatching of wagons to the cargo point is a random variable. Based on the analysis, it is established that this time is subject to the Erlang distribution of the 2nd order with density:

$$
f\left(t_{\text {ex.d }}\right)=(2 \mu)^{2} t_{\text {ex.d }}^{2} \cdot e^{-2 \mu t_{e x . d}},
$$

where $\mu$ is intensity of service.

$$
t_{\text {ex.d }}=(2 \mu)^{2} \int_{0}^{24} t_{e x . d}^{2} \cdot e^{-2 \mu t_{e x . d}} d t_{e x . d}
$$

Therefore, taking into account the research, the expenses associated with the wagons idle time for waiting to be dispatching to the cargo point, will take the form: 


$$
C_{d}^{e x}=N C_{w h}(2 \mu)^{2} \int_{0}^{24} t_{e x . d}^{2} \cdot e^{-2 \mu t_{e x . d}} d t_{\text {ex.d }}
$$

The expenses associated with the wagons idle time for waiting to be picking wagons from the cargo point after performing cargo operations with them:

$$
C_{c l}^{e x}=N t_{c l}^{e x} C_{w h}
$$

where $t_{c l}^{e x}$ is duration for waiting to be picking wagons from the cargo point.

The expenses to shunting work of the spotting / picking wagons calculated by the formula:

$$
C_{s h}=N C_{l h} \sum_{j=1}^{r} m_{j} t_{j}
$$

where $C_{l h}$ is the cost of locomotive-hours of shunting locomotive operation; $\sum_{j=1}^{r} m_{j} t_{j}-$ locomotive-hours of shunting work.

The expenses associated with the time of finding wagons in the process of spotting / picking wagons

$$
C_{f}=N t_{f} C_{f}
$$

where $t_{f}$ is the time of finding wagons in the process for spotting / picking; $C_{f}$ is the cost of one wagon -hour in freight traffic.

The expenses associated with the expectation of wagons to perform freight operations:

$$
C_{f o}^{e x}=N t_{f o}^{e x} C_{w h}
$$

where $t_{f o}^{e x}$ is the waiting wagons time to perform freight operations.

The expenses to technical and commercial inspections of wagons

$$
C_{t c}=\frac{C_{i n s}}{N},
$$


REVISTA DE LA UNIVERSIDAD DEL ZULIA. 3ª época. Año $13 \mathrm{~N}^{\circ}$ 36, 2022

Hanna Sergiivna Baulina et al. // Forming a rational technology for service cargo points... 357-372 DOI: http://dx.doi.org/10.46925//rdluz.36.23

where $C_{i n s}$ is the cost of inspection the wagons by employees of technical and commercial inspection points.

Fine for late delivery of goods, if the delay is the fault of the adjacent station:

$$
C_{f}^{g}=f\left(t_{a a}, t_{d}, t_{d o c}\right),
$$

where $t_{a a}$ - the actual time of arrival of the consignment at the station; $t_{d o c}$ is the time for crediting the transport documents.

Finally, the model to determine the optimal number of local wagons, which are fed to the cargo point at railway connecting lines of industrial enterprises with performing the system of restrictions (2) is as follows:

$$
\begin{aligned}
& C(N)=\frac{C_{s t} \sum_{i=1}^{k} N_{i} t_{i}}{\lambda}+N C_{w h}(2 \mu)^{2} \int_{0}^{24} t_{e x . d}^{2} \cdot e^{-2 \mu t_{e x . d}} d t_{e x . d}+N t_{c l}^{e x} C_{w h}+ \\
& +N C_{l h} \sum_{j=1}^{r} m_{j} t_{j}+N t_{f} C_{f}+N t_{f o}^{e x} C_{w h}+\frac{C_{i n s}}{N}+C_{f}^{g} \rightarrow \min
\end{aligned}
$$

The proposed model makes it possible to determine the rational technology for service cargo points at railway connecting lines of industrial enterprises, which will reduce the amount of payments under penalties. Taking into account the relevant system of restrictions (2), it is possible to determine the rational number of wagons in the dispatching to the railway connecting lines of an industrial enterprise. The application of the model will reduce unproductive wagons idle time at the station while reducing penalties for non-compliance with contractual terms. At the same time, this technology will allow operational staff to rationally organize the work of spotting / picking wagons from the cargo point with minimal expenses.

The implementation of the model has shown that it is possible to determine a rational technology with constantly changing volumes of work. The simulation was performed in the MATLAB environment (Figure 4). 
REVISTA DE LA UNIVERSIDAD DEL ZULIA. $3^{a}$ época. Año $13 \mathrm{~N}^{\circ} 36,2022$

Hanna Sergiivna Baulina et al. // Forming a rational technology for service cargo points... 357-372

DOI: http://dx.doi.org/10.46925//rdluz.36.23

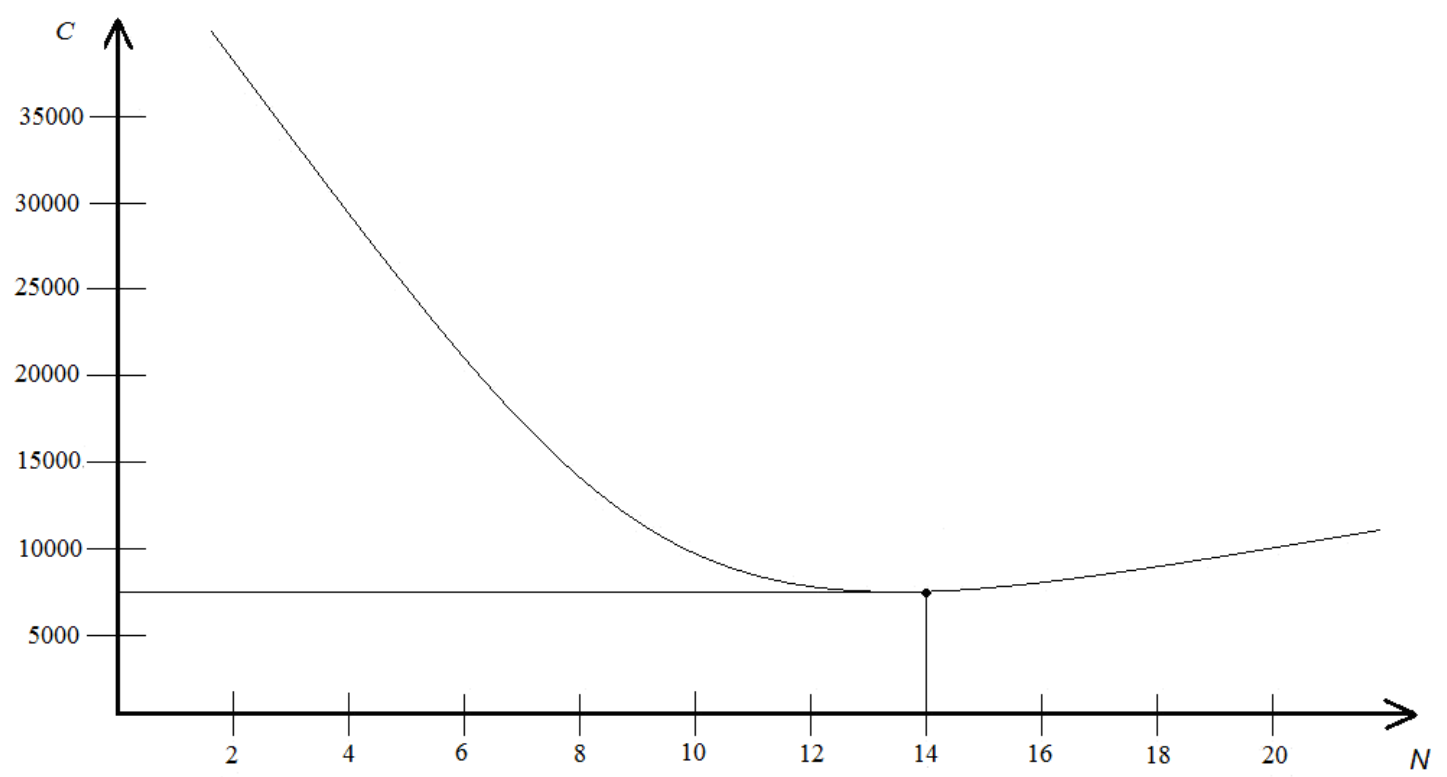

Figure 4. Dependence of operating costs on the number of wagon for dispatching to the railway connecting line of an

Source: authors

A significant achievement of this study is the creation of a model of rational technology for servicing cargo points of railway connecting lines of industrial enterprises. The developed model takes into account the probabilistic nature of the waiting time for dispatching of wagons to the cargo points, in contrast to the studies (Zapara and Garbuzov, 2015; Yelovoy and Potylkin, 2016; Prodashchuk et al., 2017; Shumik et al., 2016). An exceptional feature of the proposed model, in contrast to the works analyzed in the first section of this article, is the consideration of penalties for violation of the delivery time. Failure to comply with the terms of the contract may result in the payment by the railway of fines on claims and lawsuits of cargo owners. Taking into account the considered parameters of the mathematical model makes it possible to reduce the idle time of the local wagon at the station and reduce penalties for non-compliance with contractual obligations.

\section{Conclusions}

The detailed analysis of comparison of planned and actual values of local wagons idle time for 2016 - 2020 is carried out. The authors found that there are significant deviations from targets. The longest downtime of the local wagon at the station can be observed in 2020 , it amounted to 82.76 hours - this is $38 \%$ more than planned. The reasons for this are 
REVISTA DE LA UNIVERSIDAD DEL ZULIA. 3e época. Año $13 \mathrm{~N}^{\circ}$ 36, 2022 Hanna Sergiivna Baulina et al. // Forming a rational technology for service cargo points... 357-372 DOI: http://dx.doi.org/10.46925//rdluz.36.23

significant wagons idle time waiting for various technological operations, namely: waiting for dispatching of wagons to the railway connecting lines of industrial enterprises, waiting for unloading and loading operations, waiting for picking wagons from the railway connecting lines of industrial enterprises to the station.

In the paper forms a model of rational technology for service cargo points of railway connecting lines of industrial enterprises, taking into account possible penalties related to non-compliance with the deadline for delivery of goods to the destination. The proposed model in the implementation of the relevant system of restrictions will determine the rational number of wagons in the dispatching to the cargo point of enterprises and reduce the amount of payments for penalties.

\section{References}

Baulina, H. S. (2013). The formation of an optimization model of the cargo front operation. Informatsiino-keruiuchi systemy na zaliznychnomu transporti, 5, 44-46.

Baulina, G. S., Zakharova, I. V. (2017). Improving the technology of interaction between the freight station and adjacent access roads. International transport infrastructure, industrial centers and corporate logistics: abstracts of 13th International Scientific and Practical Conference. The bulletin of transport and industry economics. Kharkiv, June 8-10, 58 (special issue), Addition, 80-81.

Baulina, H. S., Bohomazova, H. Ye. (2020). Formalization of the technology of the port station when interacting with the port. Development of Education, Science and Business: Results 2020: abstracts of the International Scientific and Practical Internet Conference, Dnipro, December 3-4, 1, 131-132.

Baulina, H. S., Bohomazova, H. Ye., Prokhorov, V. M., Prodashchuk, S. M. (2021). Improving the efficiency of wagon flow management in servicing railway sidings. Reliability and durability of railway transport engineering structure and buildings: abstracts of 9th International Scientific Conference. Kharkiv, Ukraine, November 17-19, 30-31.

Butko, T., Kostiennikov, O., Parkhomenko, L., Prokhorov, V., Bogomazova, G. (2019) Formation of an automated technology of cargo transportation control on the direction. Eastern-European journal of enterprise technologies, 1.3 (97), 6-13. DOI: https://doi.org/10.15587/1729-4061.2019.156098

Fukasawa, R., de Aragao, M. P., Porto, O., Uchoa, E. (2002). Solving the freight car flow problem to optimality. Electronic Notes in Theoretical Computer Science, 66 (6), 42-52. DOI: https://doi.org/10.1016/S1571-0661(04)80528-0 
REVISTA DE LA UNIVERSIDAD DEL ZULIA. $3^{a}$ época. Año $13 \mathrm{~N}^{\circ}$ 36, 2022

Hanna Sergiivna Baulina et al. // Forming a rational technology for service cargo points... 357-372 DOI: http://dx.doi.org/10.46925//rdluz.36.23

Lawley, M., Parmeshwaran, V., Richard, J. P., Turkcan, A., Dalal, M., Ramcharan, D. (2008). A time-space scheduling model for optimizing recurring bulk railcar deliveries. Transportation Research Part B, 42 (6), 438-454. DOI: https://doi.org/10.1016/j.trb.2007.10.001

Miletska, I. M. (2010). Research of indicators of cargo work in places of non-public use in the conditions of the enterprise D. Zbirnyk naukovykh prats Ukrainskoi derzhavnohoi akademii zaliznychnoho transport, 118, 220-225.

Narisetty, A. K., Richard, J. P., Ramcharan, D., Murphy, D., Minks, G., Fuller, J. (2008). An optimization model for empty freight car assignment at Union Pacific Railroad. Interfaces, 38 (2), 89-102.

Prodashchuk, S., Shapoval, G., Bogomazova, G., Prodashchuk M. (2017). The study of the distribution of the loading and unloading resources when performing cargo operations. Zbirnyk naukovykh prats Ukrainskoho derzhavnoho universytetu zaliznychnoho transport, 172, 13-20.

Rakhmangulov, A., Kolga, A., Osintsev, N., Stolpovskikh, I., Sladkowski, A. (2014). Mathematical model of optimal empty rail car distribution at railway transport nodes. Transport problems. 9 (3), 125-132.

Sayarshad, H. R., Marler, T. (2010). A new multi-objective optimization formulation for railcar fleet sizing problems. Operational Research: An International Journal, 10 (2), 175-198. DOI: https://doi.org/10.1007/s12351-009-0068-0

Shumik, D. V., Peleshko, S. I., Stronsky, N. I. (2016). Improving interaction sorting stations and sidings of large public companies. Zbirnyk naukovykh prats Ukrainskoho derzhavnoho universytetu zaliznychnoho transportu, 165, 232-240.

Yelovoy, I. A., Potylkin, Ye. N. (2016). Calculation of optimal intervals to choose the modes of interaction between stations and non-public tracks. Nauka ta progres transportu. Visnyk Dnipropetrovskoho natsionalnoho universytetu zaliznychnoho transportu, 5 (65), 30-40.

Zapara, Ya. V., Garbuzov, V. O. ( 2015). Technology development model work conditions access roads to iron ore. Zbirnyk naukovykh prats Ukrainskoho derzhavnoho universytetu zaliznychnoho transportu, 152, 5 - 10. 